\title{
THE IMPLEMENTATION OF \\ PRINCIPLES IN MAKING DIVORCE \\ DIFFICULT AS THE GENERAL \\ EXPLANATION OF LAW NUMBER 1 OF \\ 1974 CONCERNING MARRIAGE IN SERUI RELIGIOUS COURT
}

\author{
Muhammad Ilham \\ Serui Religious Court \\ Jl. Irian, Kelurahan Serui Kota, Kec. Yapen Selatan, \\ Kabupaten Kepulauan Yapen, Papua 98213 \\ Email: muhilhamsyafitrah@gmail.com
}

\begin{abstract}
The purpose of this study was to determine and find out how the application and form of implementation of the principle of complicating divorce cases in the Class II Serui Religious Court. The data sources of this research are divorce case documents ranging from lawsuit/divorce applications, BAS (Session Minutes), and decisions or decisions issued by the panel of judges. This research is qualitative descriptive field research that takes place in Class II Serui Religious Court. The approach used is the juridical, syar'i, anthropological, and sociological approaches. The data collection obtained in the field is by analyzing observation techniques, interviews, and documentation. The results of this study indicate that in general the principle of complicating divorce in the Serui Religious Court is quite good, this is inseparable from the free time available for the assembly and mediator to reconcile husband and wife in divorce proceedings.
\end{abstract}

Keywords: Principle, Religious Court, Serui, Mediator 


\section{Introduction}

Marriage is a blessing that Allah bestows on His servants, therefore if a divorce occurs, it means that there is denial or disbelief in the blessings that Allah has given. ${ }^{1}$ Islam considers that marriage is something sacred. He was bound by a bond which was named Allah mitsaaqan galizan (a very strong bond). He is bound by the sentence of Allah, so with that marriage, a relationship will be established with Allah and with the parents of each partner. Litigation in marriage means litigating in religion. Because the impact of marriage is very large and extensive, therefore one of the principles of marriage which is mandated is marriage forever. The marriage bond must always be maintained and fostered so that the knot that has been tied over time becomes tighter. As for divorce, although it is permissible if forced, it is still something that God hates the most ${ }^{2}$ That is why the Islamic religion forbids marriage whose purpose is temporary, for a certain time, or simply to let go of lust. ${ }^{3}$

Thus, marriage is not only a husband-wife affair with their respective partners but also a matter for both of them with Allah SWT ${ }^{4}$. Because marriage has so far been

1 Ahmad al-Gundur, al-Talaq fi Syari'at al-Islamiyyah wal Qanun (Kairo: Dar al-Ma'arif, t.th), p. 38

2 M. Quraish Shihab, Religious Vocabulary (South Tangerang: Lentera Hati, 2020), p. 226.

${ }^{3}$ Kamal Muchtar, Principles of Islamic Law on Marriage (Jakarta: PT. Bulan Bintang, 2004), p. 157.

4 Nur Rofiah, Muslimah Critical Reasoning, Reflections on womanhood, humanity, and Islam (Bandung: Afkaruna, 2020), p. 57. 
considered very sacred worship, especially in Islam, the laws and regulations in Indonesia through the Compilation of Islamic Law Article 2 confirms that:

Marriage according to Islamic law is marriage, which is a very strong contract or mitsaqan galizan to obey Allah's orders and carry out it is worship. ${ }^{5}$

This means that marriage is a tight knot in Islam, so to maintain a strong knot or bond, therefore a concept of prevention is needed so that the couple who has been bound in marriage can remain intact and lasting as is the sacredness of the contract. Because it is not a strong contract if the marriage is only as long as the corn. Or is it not a strong bond if the quarrel and the causes of divorce are stronger than the knot of the marriage bond itself. Therefore, the sacredness that has attached and unites husband and wife in the marriage bond, the strength of the knot must be stronger than the reasons for divorce.

Marriage is not always smooth and lasting. There are times when the harmony in the household shakes when the husband and wife are involved in disputes and quarrels so that disputes and domestic turmoil often end up at the court table. The sacred contract that unites them is in danger of being torn apart if one of the couples takes the dispute to the court for trial. If this is not prevented by various existing legal instruments, then sacredness and strong ties as contained in

5 The Republic of Indonesia, Compilation of Islamic Law, Chapter II Article 2. 
the marriage contract have the potential to become tasteless or become mere slogans.

How is it that the marriage bond can be called a strong tie but the procedure for untying the strong ropes made easier? Marriage ties that can be broken down for trivial reasons, especially by arbitrary means without merit and human considerations, are no longer strong, they have even lost their sacredness. Therefore, the knot in marriage, even though it is strong and sturdy, requires an instrument and more comprehensive law enforcement so that marriage in its sacredness is maintained.

In the General Elucidation of Law of the Republic of Indonesia Number 1 of 1974 concerning Marriage in number 4 letter (e) which reads:

Since the purpose of marriage is to form a family that is eternally happy and prosperous, this Law adopts the principle of making divorce difficult. To allow a divorce, there must be certain reasons and it must be done before the Court Hearing. ${ }^{6}$

From the general explanation, there is a principle or principles adhered to by the Marriage Law in Indonesia that divorce cases must be complicated. This also shows that the indication that divorce eases or relaxes is against the purpose of marriage. Or in other words that the actions of the judicial

${ }^{6}$ The Republic of Indonesia, General Elucidation of Law of the Republic of Indonesia Number 1 of 1974 concerning Marriage, Number 4 letter e. 
apparatus that relax divorce are a form of resistance to the noble purpose of marriage. According to Sudarsono, the purpose of marriage is to form a happy and eternal family, for that husband and wife need to help and complement each other, so that each can develop his personality and help and achieve his welfare, both from a spiritual and material side. ${ }^{7}$

The principle of complicating divorce stipulates that there are certain reasons to allow the divorce to occur, and must be carried out in court. These two prerequisites are conditions that must be passed by the parties in a case to break the marriage rope. This principle requires certain reasons which later become patrons and standards in the arguments for divorce of justice seekers who go to court. By establishing certain reasons in the divorce procedure, this principle is a form of prevention for one of the partners so that it is not easy, let alone arbitrarily file a divorce case.

\section{Theoretical Review}

Law Number 1 of 1974 concerning Marriage adheres to the principle of making divorce difficult. This makes it difficult because it has to be for "certain reasons" and it must be carried out in front of the court. Besides, the existence of this principle is a form of manifestation of the purpose of marriage as required by law, namely to form a happy, eternal, and prosperous family. With the indication of the relaxation

7 Sudarsono, National Marriage Law (Jakarta: Rineka Cipta, 1991), p. 10. 
of divorce, it is an act that is contrary to the principle of complicating divorce and is also against the objectives of the law. By preventing divorce from happening, is a form of effort to realize the lofty ideals of the law.

With the birth of the principle of complicating divorce cases in Law Number 1 of 1974 concerning Marriage, it can be interpreted that before the birth of this law, husband and wife couples could easily break the marriage rope without having to go to court to be examined and reconciled first. The marriage bond seems to lose its sacredness which can be broken and dissolved anytime and anywhere. With the existence of the principle of complicating divorce as contained in Law Number 1 of 1974 concerning Marriage, divorce actions that threaten the marriage that has been fostered by a husband and wife can be prevented and exchanged. Therefore, it is not an exaggeration if the birth of the principle of complicating divorce is a form of the state's presence in protecting and saving the household's ark of its citizens. Even as a form of affirmation that the state is present in every side of the life of the nation and state, including in this marriage service.

The following is the application of the principle of complicating divorce cases as contained by Law Number 1 of 1974 concerning marriage.

\section{Divorce Must Be Before Trial}




\section{Muhammad Ilham}

The Religious Court is a state institution legally appointed by law to handle divorce cases that occur especially for Muslims in Indonesia. This is clearly stated in Article 65 of Law Number 7 of 1989 concerning Religious Courts, that;

Divorce can only be carried out before a court session after the court concerned has tried and failed to reconcile the two parties " 8

It is intended that all legal actions that occur have permanent legal force and can be accounted for. According to Ahmad Rofiq, that if marriage and divorce are examined further, the involvement of the court in the divorce between husband and wife has very positive aims and objectives. Apart from that for the sake of formal juridical purposes, the trial process which can hardly be completed in one or two trials is to provide an opportunity for both parties to always think about their steps to divorce. Moreover, the court must seek peace between the two parties at every opportunity. ${ }^{9}$

The Religious Court as the executor of judicial power in the field of family law will also determine the level of success in realizing the ideals of a prosperous family ${ }^{10}$. Thus, the last gate for a marriage is a religious court. And every judicial apparatus is at the forefront of preventing divorce.

8 The Republic of Indonesia, Law Number 7 of 1989 concerning Religious Courts, Article 65.

9 Ahmad Rofiq, Islamic Law in Indonesia (Cet.II; Jakarta: PT. Raja Grafindo, 1997), p. 318.

10 Busthanul Arifin, Institutionalizing Islamic Law in Indonesia (Cet. I; Jakarta: Gema Insani, 1996), p. 151. 
The integrity of each judicial apparatus is one of the inseparable links to realize this principle optimally. Concerning household disputes that have reached court as cases, as much as possible by each judicial apparatus to prevent marriages can be maintained so that divorce does not occur.

However, the reality shows differences, there are still many people who insist on the old tradition, that a man has the right to drop divorce whenever and wherever he wants. With the promulgation of Law Number 1 of 1974 concerning Marriage which became effective on October 1, 1975, then one of the principles in the Law was "divorce made difficult". This means that for a divorce to occur, it must be submitted to the court, state the reasons that cause the filing of the petition/lawsuit, and by the judge, if it is proven, the judge then decides with a verdict: to permit the applicant to pledge divorce or to impose talak bain. ${ }^{11}$

So, just for a case must be done in court, then divorce or divorce that is pledged outside the court is considered invalid or called illegal divorce which has no legal force whatsoever. By litigating in court, divorce is not only prevented and made difficultly but also to confirm every legal act that results from the divorce.

11 Habiburrahman, Bunga Rampai Religious Courts, 2015, p. 178. 


\section{Certain reasons}

Divorce not only has to be done before the court, but divorce must also be included with "certain reasons" which become the legal basis for justice seekers in filing a divorce suit. Divorce shouldn't happen just because of the agreement between husband and wife, there must be valid reasons for this ${ }^{12}$ How could the marriage bond as referred to in the Qur'an as mitsaqan ghalizan (strong bond) could be broken if the reason for divorce was not stronger than the marriage bond itself? This strong bond called the Koran is then accommodated by the values and spirit contained in the law by specifying certain reasons for filing for divorce. The sentence "Based on the Almighty Godhead" contained in article 1 of the Marriage Law, also confirms that marriage with all its consequences (including divorce) is a matter of faith. ${ }^{13}$

\section{Research methodology}

This research uses qualitative research, namely research that emphasizes the search for meaning, understanding, concepts, characteristics, symptoms, symbols, or descriptions of a phenomenon that is used as the object

12 Zaeni Asyhadie, Civil Law in the Perspective of National Law (Cet. I; Depok: PT. Rajagrafindo Persada, 2018), p. 158.

13 Bismar Siregar, Interfaith Mixed Marriage How the Solution, (In Varia Judiciary Magazine; Jakarta: Number 75, December 1991, pp. 145-147, quoted in Umar Shihab, Contextuality of the Koran, (Cet.III; Jakarta: Penamadani, 2005), p.325. 
under study ${ }^{14}$. The qualitative approach by the researcher aims to understand or understand the symptoms under study. Researchers research to draw out legal principles (rechsbeginselen) that can be applied to written and unwritten law $^{15}$. The prevailing laws and regulations are linked to legal theory and positive legal practice concerning the problem, which will then be analyzed as an answer to the problems that have occurred so far. Based on the problems to be examined by researchers, this is in line with Nugrahani's view, that qualitative research is to understand the conditions of a context by directing a description, in detail and depth, of a portrait of conditions in a natural context (natural setting), concerning the real occurs according to what it is in the field of study. ${ }^{16}$

\section{Results and Discussion}

The researcher obtained information about how the views of the judges at the Serui Religious Court in understanding the substance of making divorce difficult when viewed from both Islamic law and positive law. His Excellency Deputy Chairman of the Religious Court Serui

14 Soerjana Soekanto, Introduction to Legal Research (Jakarta: UI Press, 1986),

${ }^{15}$ p. 32. Soerjana Soekanto, Introduction to Legal Research p. 32.

16 Nugrahani. F, Qualitative Research Methods, (Solo; Cakra Books, 2014), quoted in, Andi Puteri Mangkawani, Thesis, The Pragmatic Meaning of Signs in Commercial Product Advertisements for Charles Sanders Peirce's Semiotic Studies, Postgraduate Language Education Study Program (Makassar State University, 2020), h. 42. 
Moch. Syah Ariyanto, S.HI stated that divorce in Indonesia is not only protected by religion, but the state is also involved in the settlement process. Like marriage, divorce must also be registered. In order not to have an illegal divorce that is carried out outside of court, our country requires that divorce must be done before trial. Thus, divorce will not automatically be made easy or at least more difficult. Divorce is made difficult because the impact it causes is not only on the divorcing family but can extend to society. The existence of an attitude of revenge, hatred, is the attitude that results from the divorce. Therefore, it is only natural, if then religion and the state took part in the process of complicating it.

Within the jurisdiction of the Serui Religious Court, it is known that there are still many illegal divorce practices carried out by the community. Even though divorce or talak imposed without involving a religious court is not only a violation of the law but the legal act results in many losses to the person concerned. One example of the community in Dawai (one of the districts in the jurisdiction of the Serui Religious Court) is still practicing illegal divorce or illegal divorce so that employing illegal divorce they think that the divorce is legal and can be used as a basis for remarrying someone else. So, the divorce process has not yet been filed in court, but the person concerned has remarried. This is also inseparable from the existence of certain individuals who marry them off in unison. These irresponsible individuals are usually used as the basis by the community so that residents 
in the Dawai area dare to pledge divorce outside the Serui Religious Court, and remarry.

The Serui Religious Court needs to disseminate information to the public that divorce in Indonesia is not only subject to fiqh or religious law, but the state with its administration and legislation must be involved for orderly legal actions in society. Domestic affairs are the responsibility of the state administratively so that the legal status or legal actions taken are clear. All this is done to protect the rights of citizens in carrying out the teachings of their respective religions. By referring to the law, the procedure for divorce requires certain reasons and must be proven in court. The stipulation of these reasons also indicates that marriage is a sacred and strong bond, so to let go of it also must be with strong reasons. Religion and state do not allow marriage without proper and proper reasons. With a procedure like this, divorce becomes even more difficult, in contrast to illegal divorce, it can be a petty fight or dispute, or even for no apparent reason, then the husband says the word divorce. By stipulating that divorce must be for certain reasons and must be carried out before the court, divorce is in line with religious values that the marriage bond is a sacred bond, which must be maintained. Those are the religious values played by the state in curbing marriage and divorce in positive law ${ }^{17}$

${ }^{17}$ Interview, Moch. Syah Ariyanto, S.H. (41 years old), Deputy Chairman of the Serui Religious Court, Monday, November 30, 2020 
As for the opinion expressed by His Excellency Sriyanto, S.HI., M.H, divorce indeed has the potential to bring Allah swt wrath. Because marriage is a blessing that Allah bestows upon His servants. However, if there is chaos in a household so that all efforts for peace that have been made by both the family of the litigant and the court have been carried out but have found no solution other than divorce, then this is permitted. Because even household turmoil can also be said to have the potential to bring the wrath of God Almighty. A household that is not harmonious, where there is no more peace in it, can also invite the anger of Allah Almighty. Therefore, divorce is the last alternative offered by the religion of Islam if the household situation is no longer hope to be maintained so that the married couple can escape each other from the misery of running the household.

As for the effort to complicate divorce cases at the Serui Religious Court, the indicator is whether or not the principle of complicating divorce is applied by the court is not measured by the reconciliation of the parties in the case so that the case that occurred or not was withdrawn. However, the indicator of success or application of suppressing divorce in the Serui Religious Court is measured in three ways, the first is the attempt to reconcile by the panel of judges every time a trial starts. Second is the application of mediation when the parties in a case are all present at the trial. Meanwhile, the third is proof that the parties in the case must go through. If these three things have been carried out by the court, 
regardless of the success or failure of the peace, regardless of the harmony or failure of the parties in the case, the effort can be said to be an indicator of success for an assembly in realizing the principle of complicating divorce cases ${ }^{18}$

Meanwhile, what was stated by His Excellency Syaukani, S.Sy regarding divorce from the perspective of Islamic law is that in the Koran many verses explain the procedures for divorce. Meanwhile, the divorce that is allowed even though it is hated by Allah SW'T comes from the hadith of the Prophet Muhammad. So, it is important for us to examine the two sources of reference for Muslims, namely the Koran and the Hadith, because, on the one hand, the hadiths explain that divorce is hated, but on the other hand, it is the Koran that clearly explains it. about the divorce ordinances. So, it creates a contradictory impression, so that Allah swt hates divorce cases not based on strong reasons or grounds. In the book Kifayat al-Ahyar it is stated that the Prophet Muhammad (s) granted the divorce of a woman who complained to him, that she had a husband who was not religious. The Prophet Muhammad's granting of the divorce proposed by the woman is an indication that the Prophet allowed the divorce, as long as it is included with strong and correct reasons. The effort to complicate divorce cases in positive law at the Serui Religious Court is that the notion of the principle of complicating divorce cases is a formal

18 Interview, Sriyanto, S.H., M.H. (39 years), Serui Religious Court Judge, Friday, November 13, 2020. 
procedure. Therefore, a household dispute that has been litigated by one of the spouses must be processed or examined before a court by a panel of judges. This kind of procedure also shows that in the case of divorce, one spouse is not allowed to file a lawsuit/application for divorce without clear reasons ${ }^{19}$.

So, the perspective of the judiciary apparatus on complicating divorce from the perspective of Islamic law is a case that starts from a sacred act, so that it is not only related to religion alone but must involve the state in this case the divorce process must involve the state without having to ignore religious teachings. . Divorce is a failure in building a household so that people in pursuing a divorce must involve the state, in this case, legal actions regarding divorce must be submitted to the competent judiciary. The reasons for divorce must contain human values and be far from arbitrary, so the reasons that must be put forward by the parties in the case must be based on merit and cannot be separated from human values.

Likewise in positive law, the principle of complicating divorce has nothing to do with the process of case examination in court. This principle is nothing but to regulate order so that no more divorces are carried out outside the court or what is commonly referred to as illegal divorce. With

${ }^{19}$ Interview, Syaukani, S.Sy. (30 years old), Serui Religious Court Judge, Monday, November 16, 2020. 
the existence of a principle or principles of complicating divorce cases as contained in Law Number 1 of 1974 concerning Marriage, such procedures have made divorce difficult, because, in addition to requiring certain reasons, it also requires that the divorce be carried out before the trial. . Because it must be carried out before the court, the effort to complicate the divorce case is further emphasized by the existence of a lawsuit that must be filed by the parties in the case whether it is following the main requirements of the lawsuit or not.

The lawsuit must include the identities of the parties first, which is then followed by posita, or the bases for filing a lawsuit or petition such as a statement of a legal event concerning the marriage of the parties in the case recorded by the KUA which is included with the marriage certificate number, as a result of the marriage as being a gifted child or not. In this part of the posita, certain reasons as required by the laws and regulations must be fulfilled by the litigant in the lawsuit/application for divorce. Finally, followed by a petitum, namely the request or purpose for the filing of the lawsuit or application. When entering the process at trial, the plaintiff is charged with evidence to prove the arguments of the lawsuit as stated in the posita. Such a series of procedures that litigants have to go through to divorce in court are considered quite difficult so that divorce is not carried out arbitrarily. 
Efforts to Reduce the Divorce Rate in the Serui Religious Court

According to the observations of researchers, there is a special phenomenon that occurs at the Serui Religious Court, which is closely related to the principle of complicating divorce cases when it is linked to holidays for employees or agencies in Papua. Based on the policy of the Papua Provincial Government which has become a tradition and has been applied from generation to generation, that at the end of the year, the days of collective leave are set, especially ahead of Christmas and New Year. A large number of holidays in a year determined by the Papua Provincial Government, resulting in fewer office workdays, especially before Christmas and New Year. This condition cannot be separated from anthropological factors and local social conditions, namely the dominance of indigenous Papuans who adhere to Christianity as the main factor. Finally, the Governor of the Papua Provincial Government issues a decision through a circular at the end of each year or before Christmas about the number of holidays on collective leave.

For example, the Decree of the Governor of Papua Number 188.4 / 489/2018 concerning Official Holidays and Joint Leave in the Papua Province in 2019, the number of Official Holidays throughout 2019 is set at 25 days and Joint Leave for 14 days. The circular is described in detail in letter (A) concerning "Official Holidays" in numbers (23), (24), and (25). Number (23) states that December 25, 2019, is the First 
Christmas Day, then in number (24), it is stated that December 26, 2019, is the Second Christmas Day, and followed by the number (25) it is stated that December 27 is the Anniversary of the Province of Papua. Whereas in letter (B) concerning Joint Leave Days number (6) it is stated that December 18-24, 2019 is a joint leave holiday before Christmas. So, in the letter, starting from December 18 to December 27 is a holiday stipulated by the Papua Provincial Government.

The policy stipulates the greater number of holidays, the more the number is added to the Saturday and Sunday holidays outside the days specified in the circular. In total, the number of days in December 2019 will reach 17 days. More than half of the normal days in December are holidays in Papua Province. Because all of the panels of judges are migrants, they take advantage of their annual leave to fill the workdays that occur in December. As a result, the judges who went home in December would not arrive back in January of the following year.

This policy has an impact on the leadership policies implemented in the Serui Religious Court. According to the observations of researchers at the Serui Religious Court, there was a policy from the previous leaders from generation to generation so that it became a habit, namely the closing of case registrations before December. And this policy is still in effect until this research is carried out. The Serui Religious Court's decision to close the case registration had several 
reasons. Namely, in addition to allowing judges to go home at the end of the year, this is also intended so that procedural law can be carried out properly, namely to maintain the distance between the date of registration of the case and the day of the first trial.

Because the registration is still open near the end of the year or December, then this procedure has the potential to make procedural law not working properly, such as causing too long a distance between the registration date and the trial day, because the new panel of judges will return to serve in January. next year. There is a defined distance between the date of registration of the case and the day of the trial, in addition to several sets of administrative procedures that must be fulfilled also as an opportunity for the parties to prepare themselves to attend the trial. After the case is registered, the head of the court issues a decision of the panel of judges who will hear the case. After that, the judge who is appointed as chairman of the panel issues a decision on the day of trial, which is then appointed by the court clerk to appoint the bailiff to summon the parties to appear before the trial on the day determined by the chairman of the panel.

As is well known, the delivery of a summons for trial, which is usually referred to as relaas, which is delivered by the bailiff to the plaintiff or defendant to attend the first trial, must legally and properly be delivered no later than 3 working days before the day the trial is held. Therefore, the gap between the date of registration of the case and the day of the 
first trial is intended so that these days are intended for preparation for the day of the trial, both for litigants and judicial officers.

According to researchers, closing the case registration which has become a habit at the end of every year, including in this case the divorce case at the Serui Religious Court, is a policy that indirectly serves to restrain the divorce rate or at least detain potential litigants so that can postpone their household disputes to be litigated in court. This postponement has the potential to provide space or opportunity for litigants, especially husband and wife, to think more carefully, not to be arbitrary or hasty, before finally registering the dispute as a case in court. That is why a few weeks before the end of the year, the Serui Religious Court leadership took a policy to stop the case registration process. According to researchers, the closure of the case registration can be categorized as an effort to reduce the divorce rate at the Serui Religious Court. When judges have returned to duty after a joint holiday or national leave, no one can ensure that potential litigants who were previously detained from registering cases will return to file cases again.

Researchers found that the return of the candidate parties to the case to re-register their cases became completely uncertain after the judicial apparatus and judges returned to duty after a joint holiday or national leave. Because the 
household conditions are dynamic. It may be that today a married couple is fighting and arguing with each other, but later on, they will get back together and be as harmonious as before. Justice seekers who want to register their cases ahead of collective leave may at that time the household is in cracks and there is no harmony. But after several weeks and registration is reopened, the household situation may return to harmony and harmony, so that the dispute that was originally intended to be litigated eventually becomes canceled to be registered.

The heart and psychological condition of a married couple who can be dynamic every day are the main reasons why a pending divorce case is not guaranteed to be registered again. This is based on one of the researchers' findings in case Number 36 / Pdt.G / 2020.PA.Sri. and 28 / Pdt.G / 2020 / PA.Sri at the Serui Religious Court which was revoked by the panel because of the petition of one of the litigants who wanted to first resolve the problem outside the jurisdiction of the religious court, so the litigants asked the assembly verbally so that the case that is running must be unplugged first. This situation becomes increasingly uncertain in the future, that the dispute that has been revoked will be registered and brought back to trial after the problem that the parties in the case want to resolve has been resolved. It could be because problems outside the court have not yet met a common ground, or it could be because the two of them are getting along and harmonious. If those who have litigated cannot be sure that 
they will return to litigation after the case is withdrawn, then what about disputes between husband and wife whose registration has never been carried out?

Thus, the researcher argues that the closure of case registrations carried out by the Serui Religious Court has the potential to be used as an important momentum for husband and wife, or a turning point for disputes, that the domestic turmoil that has been experienced by the litigants has become canceled to be registered as a case.

\section{Forms of Application of the Principle of Complicating Divorce in the Serui Religious CourtDuration of the Field Trial}

As the researcher has explained, one of the supporting factors in realizing the implementation of the principle of complicating divorce cases at the Serui Religious Court is the time or duration of the trial available, so that the advice and all forms of peace that the panel of judges strives for in the trial can be freely applied optimally. The average number of trial durations at the Serui Religious Court is 1,119 minutes or approximately 18 hours of trial duration for each case. Such a duration is counted from the identity check agenda at the initial trial to the final trial stage or the reading of the decision. Therefore, the length of a broad trial is an opportunity for the panel of judges to apply the principle of complicating divorce. With a broad duration, the peace efforts by the panel of judges will be effective and of high quality, not only in passing or 
formally. The peace effort has more weight because it can be filled with several pieces of advice, or inducements, and all of these can be carried out by each member of the panel of judges without worrying about the time or waiting for other parties who usually queue up for trial as has happened in other courts. in general. The chairman of the panel can freely invite each of the other members of the panel of judges to convey peaceful advice to the litigant such as religious advice. In this way, the tension and emotions that often arise between the parties in the trial can be calmed down before getting to the point of the case.

In the context of realizing quality peace efforts, the duration of up to 18 hours for each case is a great opportunity for each member of the assembly to implement peace in the courtroom so that the parties in the case can return to harmony and harmony. The results of the researcher interview with the Serui Religious Court Judges about how to respond to the free trial duration available at the Serui Religious Court resulted in various attitudes.

His Excellency Deputy Chairman of the Serui Religious Court, Moch. Syah Ariyanto, S.H.I., in terms of optimizing the duration of a broad trial, argued that it is certain that a court with a small number of cases will have an impact on the duration of available trials. The fewer the number of cases received by the court, the greater the duration of the trial and the duration of negotiations in 
mediation. Conversely, the more cases a court receives, the less trial duration will be available.

Therefore, the Serui Religious Court, which has a relatively low number of cases each year, can make the maximum use of the available trial duration in the trial to reconcile the parties in the case. Peace efforts, or advice, became an area for each member of the panel of judges to convey. Of course, this kind of peace has little or no impact on the litigants. However, the available trial duration is not a guarantee or certainty about the quality of peace in the trial. The amount or not the duration is relative, depends on each member of the panel in responding to the case he is facing. A large or wide duration does not determine, it is not absolute that the quality of the trial must be supported by a large amount of duration, it is only a supporter ${ }^{20}$.

As for the information delivered by Sriyanto, S.H.I., M.H. In terms of optimizing the duration of a broad trial to realize the principle of complicating divorce cases, the application of the principle of complicating divorce cases cannot be related to the duration of the trial available in each court. Because the hypothesis states that a court with a broad trial duration will have a great chance of reconciling the parties, it can also be said that a court with a narrow trial duration will find it difficult to reconcile the parties in a case,

${ }^{20}$ Interview, Moch. Syah Ariyanto, S.H. (41 years old), Deputy Chairman of the Serui Religious Court, Monday, November 30, 2020 
or it will be difficult to apply the principle of complicating divorce.

Therefore, the understanding of the principle of complicating divorce cases cannot be measured or even has nothing to do with the duration of the trial available. Regardless of the number of trial durations contained in a judicial institution, the application of the principle of complicating divorce cases is sufficient to assess how the implementation of the peace is carried out or it is ignored by the panel of judges in the examination process ${ }^{21}$

Meanwhile, the statement delivered by His Excellency Syaukani, S.Sy. In terms of optimizing the duration of a broad trial to realize the principle of complicating divorce cases, the trial duration available in court has an important role in terms of peace in trials. Because peace is the responsibility of the panel of judges in starting the trial before entering the main examination of the case, it is important to take into account the available trial duration. The length of the trial is broad, making the peace efforts made by the panel of judges in the trial to be of higher quality. The panel of judges also freely reconciled and calmed the parties in the case, which were generally provoked by emotions or argued in the courtroom

In several lawsuits posita submitted by the litigants, the researcher found that many of the litigants had cut off

${ }^{21}$ Interview, Sriyanto, S.H., M.H. (39 years), Serui Religious Court Judge, Friday, November 13, 2020. 
communication for months before finally being able to meet in the courtroom. With the advice and efforts made by the panel of judges, the tension between the parties in the case can be resolved. But after all, not only the skill or professionalism required in carrying out peace efforts, but the duration of the trial available at the Serui Religious Court is very important and decisive to support this peace effort. Religious advice or advice in striving for peace can be used to the fullest extent possible by the panel of judges so that the stiff and tense atmosphere can return to fluid and harmony. Thus, the duration of the trial is very decisive in preventing a divorce that occurs between the parties in the case.

The free time for the panel of judges and the mediator in carrying out their functions and authorities to reconcile the parties in the case examination process makes the quality of implementation make it difficult for divorce cases to be of higher quality. Because the time available is sufficient, it is not only needed by the panel of judges in court to reconcile the parties. However, mediators also experience the same thing, that sufficient time is also needed to conduct maximum negotiations. At the Serui Religious Court, it is rarely seen that litigants queue up to carry out mediation. This means that the mediator can freely and freely carry out their duties in reconciling the parties without having to be burdened with long queues or limited time. Maximum peace efforts in the mediation process are the most important part in the series of 
realizing the principle of complicating divorce cases at the Serui Religious Court. Likewise with the trial process.

\section{a. Communicative Trial}

Geographically, the Serui Religious Court is located in a district in Papua Province called Yapen Islands Regency. Even though it is located in Papua, it does not mean that the litigants at the Serui Religious Court are dominated by indigenous Papuans. The litigants at the Serui Religious Court were dominated by migrants or migrants who came from various tribes and languages such as Javanese, Minang, and Bugis. Likewise, with the current composition of the panel of judges serving at the Serui Religious Court, not a single judge is native to Papua. All of them migrants or immigrants from various tribes, such as Javanese, Bugis, and others. The judges were often confronted by witnesses who did not understand Indonesian at all. If it turns out that the parties who do not know the use of the Indonesian language come from the same tribe as one of the members of the panel of judges, such as the Javanese or the Bugis tribe, then this situation is often used by the assembly members to dig up and find out a lot of information using the local language that is used by litigants.

This kind of communication is also commonly used by judges in other religious courts. The point that the researcher wants to convey is that the position of the Serui Religious Court, which is in the midst of the Papuan community, has no effect on the language or communication 
between the panel of judges and the litigants in the courtroom. Because after all, the litigants are dominated by migrants or migrants. Therefore, this condition is not a serious obstacle to both the panel of judges and the mediator in optimizing peace efforts without having to adapt to the local language / Papuan people.

Communication with the use of regional languages in seeking and exploring the substance of divorce case disputes is used for smooth communication that exists between the panel of judges and the litigants at the trial or in the mediation room. This is one of the reasons for making the parties in a case or witnesses in the trial communicative with the panel of judges or the mediator. With the existence of communication using the local language in the trial between the panel of judges and the parties in the case or witnesses, or negotiations in mediation between the mediator and the parties in the case, this can overcome the obstacles of the parties in conveying information in the trial. So that in such a trial the emotional relationship between the panel of judges or the mediator and the parties in the case is getting stronger. Advice or peace efforts in the courtroom are of increasingly high quality.

Thus, even though the litigant parties are unable to use the Indonesian language well in communicating both in the courtroom and in the mediation process, peace efforts can still be implemented properly with sociological and anthropological approaches, namely as the language and ethnicity between the judicial officers. and the parties in the 
case concerned, without having to adapt to the local language or the language of the Papuan people. Approaches and communication using language under the language of origin of the litigant can make the application of the principle of complicating divorce more optimal so that the litigant can cancel his intention to divorce so that the marriage can continue to be maintained, return to harmony and harmony as aspired by the law. Marriage.

\section{b. Democratic Trial}

The minimal number of cases in the Serui Religious Court makes the trials democratic. Democratic, what the researcher means is the understanding of the panel of judges to the litigant parties in the trial process, such as mistakes made by the parties in the case, forgetting to bring letters to be presented as evidence in court, or arriving late, the judge can consider it without having to burden with the trial queue. Often the litigants and witnesses arrived late, but the panel still tolerated the delay without having to be postponed to the next week. The panel of judges was willing to wait for hours just to await the arrival of the witnesses presented by the litigants.

This condition is very difficult to find in other courts that have a large number of cases, especially in courts that have thousands of cases each year. Like the researcher's experience during an apprenticeship at the Depok Religious Court, if the substitute clerk in the courtroom has summoned 
the litigants according to their queue number 3 times but has not yet appeared, due to the large number of court queues waiting, then at that time the trials of the parties who were called did not arrival will be postponed until the following week. Furthermore, the chairman of the panel ordered the substitute clerk to make an instrument of summons to be submitted to the bailiff to return to summon the litigants to come before the trial the following week or on the date determined by the panel of judges.

In contrast to what happened at the Serui Religious Court, that the delay of the parties in the case, or the parties who forgot to bring the documents to be presented as evidence in the trial, will be tolerated by the panel of judges and then invited back to collect the forgotten evidence or at least the panel did not delay it until the following week for the smooth running of the case examination process. This condition, according to the observations of researchers, is that a democratic trial like that can make the weight of the trial more qualified, as well as an opportunity to be used by the assembly in applying the principle of complicating divorce cases.

\section{Desk Clerk I}

As the rationale for which the researcher explained earlier, that to realize the principle of complicating divorce cases, the implementation of these principles must begin at the initial stage of the case process, namely during registration. 
Therefore, those who should be appointed as the desk I (one) officers or who are referred to as registration officers are those who have competence or proficiency in legal mastery, both material and formal, or at least fully understand the characteristics of disputes in divorce, in this case: "Certain reasons" as determined by laws and regulations. Certain reasons referred to are Government Regulation Number 9 of 1975 article 19 letters (a) to (f), Article 116 compilation of Islamic Law, as well as points of agreement in taklik talak.

The researcher's rationale above is strengthened by the statement conveyed by His Excellency Deputy Chairman of the Religious Court Serui Moch. Syah Ariyanto, S.HI stated that the quality of registration officers should be occupied by officers with the status of PNS (Civil Servants) who have competence in the field of law. The position of desk I (one) officer at the Serui Religious Court is filled by honorary staff, this is because the condition or number of personnel in the office is not supportive. The services provided by the table I (one) in receiving and registering cases are very substantial with the explanations and directions were given to the candidate parties to the case. So, the quality of human resources for the desk I (one) officers is very important ${ }^{22}$

The same thing was said by His Excellency Syaukani, S.Sy that in the case of divorce cases, the quality of human

22 Interview, Moch. Syah Ariyanto, S.H. (41 years old), Deputy Chairman of the Serui Religious Court, Monday, November 30, 2020. 
resources in case admissions is very influential in selecting the material content of the lawsuit. Registration officers are required to examine the lawsuit or petition materially before registering it as a case ${ }^{23}$.

The effect of the inability of the desk I (one) officers in selecting and accepting the reasons for divorce as stated in the lawsuit before being registered, is not just a problem that must be resolved to realize the principle of complicating divorce cases properly, but registration officers who do not know anything. Regarding the reasons for divorce as must be stated in a divorce suit, it can be interpreted that these conditions are a gap in the birth of an indication of the leniency of divorce cases. As a result, several household disputes did not meet the criteria for certain reasons, but in the end, the dispute turned into a case because it had been registered by the registration officer.

The names of the desk I (one) officers or commonly referred to as registration officers appointed by the Serui Religious Court Leadership based on the Decree of the Chair of the Serui Religious Court as of 6 January 2020 Number: w25-a9 / ot.01.3 / 1/2020 About the Team The One-Stop Integrated Service (PTSP) Manager of the Serui Religious Court in 2020, is Jhon L Komalakonda, SE., And Nuzul Arifin Rumbouw, SH. Both of them are temporary personnel

23 Interview, Syaukani, S.Sy (30 years), Serui Religious Court Judge, Monday, November 16, 2020. 
at the Serui Religious Court. In an interview conducted by researchers with Desk I (one) officer, Nuzul Arifin Rumbouw, SH, stated that the role of desk I (one) clerk in realizing the difficulty of making divorce cases is very important. This is because the position of the registration officer is the initial stage that justice seekers must go through and then proceed in the courtroom. The role in question is how a registration officer can register cases according to the stipulated regulations. For example, when a civil servant wants to register his case, even though he has reasons that meet the criteria for "certain reasons" as stipulated by statutory regulations, but if he has not been able to attach a certificate from his superior or leader regarding the divorce process he is doing, then the household dispute that he registers cannot be registered as a case. There is no tolerance such as the letter being attached later, this requirement must be attached to be registered as a case.

So, the efforts of the registration officer in realizing the principle of complicating the divorce are imperative that the parties in a case must meet the requirements of the divorce case such as a book or quotation from a marriage certificate, KTP, and a certificate from the institution concerned if the person who wants to litigate is a PNS (Civil Servant) ${ }^{24}$ These requirements must be fulfilled beforehand before a household

${ }^{24}$ Government Regulation of the Republic of Indonesia Number 45 of 1990 concerning Amendments to Government Regulation Number 10 of 1983 concerning Marriage and Divorce Permits for Civil Servants. 
dispute is registered as a case. On the other hand, however serious a household dispute is, if it does not meet the formal requirements, the registration officer firmly refuses.

Regarding electronic case registration, it has been instructed by the previous leadership that every case received must be registered as an e-court case. Regarding the defendant or the defendant not agreeing with it, it will be clarified in the trial. So, on the instruction of the Serui Religious Court, the registration officer has to directly direct the litigants to hear them electronically. If the parties in the case are already elderly, or it turns out that the case candidates are not supported by an "android" cellphone so that access to receive calls via e-mail or e-mail is not possible, then under these conditions the registration officer only registers the case concerned as a normal case, or trials conducted manually in the courtroom.

Regarding the registration of a divorce case if it is reviewed materially, the "certain reasons" mentioned in the General Explanation of Law Number 1 of 1974, by the Serui Religious Court's I (one) table officer admit that they do not know in detail, even the term "syiqaq" This was the first time he had heard it during an interview session conducted by researchers. But at least in carrying out their main duties, the reasons received by the desk I (one) clerk are reasons that are strongly suspected to be categorized as disputes that can be used as reasons for divorce, such as the existence of domestic violence (domestic violence) or one of the parties had left 
their partner for many years. Such reasons can be accepted by desk I (one) officers and registered as cases.

However, the fact that often occurs in the registration services of the Religious Courts is that the litigants are not always honest in disclosing the domestic disputes they experience, this is especially so for the litigants whose marriage age is still relatively young. Those in this category are generally around the age of 20 to 30s. It could be because of embarrassment, or it could be because the dispute is not yet fit for litigation. It is different if the prospective litigants have reached the age of marriage, they are more daring to reveal what happened to their household. Some of the candidate parties to the case also prefer to disclose it in court after the panel of judges has examined and explored disputes that have occurred in the households of the litigants. That is why some lawsuit or divorce requests contain reasons for divorce that at first glance feel like trivial reasons and do not deserve to be litigated because the parties themselves do not want to be open to the registrar to reveal the domestic problems they have experienced ${ }^{25}$.

\section{Conclusion}

Based on the results of the researcher's analysis of the implementation of the principle of complicating divorce cases at the Serui Religious Court, in general, the application of the

25 Interview, Nuzul Arifin Rumbouw, S.H., (25 years), Desk I (one) Officer of the Serui Religious Court, Friday, November 13, 2020. 
principle of complicating matters has been well implemented to create the goal of an eternal and prosperous marriage. However, on the other hand, it is necessary to improve the quality of reliable human resources, especially for Desk I (one) officers or registration officers to understand the character of domestic disputes or "certain reasons" as stipulated by laws and regulations. With a good understanding of the arguments for a divorce lawsuit, it will realize the enforcement of the principle of making divorce cases more maximally difficult by the judicial apparatus at the Serui Religious Court.

As for the process of reconciliation that is attempted by the panel of judges and mediators to make divorce difficult, in general, it represents the implementation of the principle of complicating divorce. The main reason why during the last 3 years the panel of judges has never implemented an attempt to appoint rights to reconcile the litigant, because this application has become a casuistic, depending on the extent to which the panel of judges deems necessary. Even though the dispute was very serious as stated in the lawsuit, the posita did not make the judges act a priori, so that peace, persuasion, and religious advice were still conveyed in the courtroom. Over the past 3 years, the panel of judges at the Serui Religious Court has reconciled 15 divorce cases. Meanwhile, the mediator in the last 3 years has succeeded in reconciling 2 divorce cases.

The peace pursued by the court has been maximized because it is supported by the available time without having 
to be burdened with time or be affected by long trial queues. This allowed the panel of judges and mediators to freely convey advice and persuade the parties to be able to return to their household. With this free time, the trial will be more qualified, communicative, and democratic.

\section{References}

Ahmad al-Gundur, al-Talaq fi Syariat al-Islamiyyah wal Qanun (Kairo: Dar al-Ma'arif, t.th)

Arifin, Busthanul. (1996) Institutionalizing Islamic Law in Indonesia (Cet. I; Jakarta: Gema Insani).

Asyhadie, Zaeni. (2018) Civil Law in the Perspective of National Law (Cet. I; Depok: PT. Rajagrafindo Persada).

Habiburrahman. (2015) Bunga Rampai Religious Courts.

Muchtar, Kamal, (2004).Principles of Islamic Law on Marriage, Jakarta: PT. Bulan Bintang.

Mangkawani, Andi Puteri. (2020) Thesis, The Pragmatic Meaning of Signs in Commercial Product

Nugrahani. F. (2014) Qualitative Research Methods, (Solo; Cakra Books)

The Republic of Indonesia, Compilation of Islamic Law, Chapter II Article 2.

The Republic of Indonesia, General Elucidation of Law of the Republic of Indonesia Number 1 of 1974 concerning Marriage, Number 4 letter e. 
The Republic of Indonesia, Law Number 7 of 1989 concerning Religious Courts, Article 65.

Rofiah, Nur. (2020) Muslimah Critical Reasoning, Reflections on womanhood, humanity and Islam (Bandung: Afkaruna).

Rofiq, Ahmad. (1997). Islamic Law in Indonesia (Cet.II; Jakarta: PT. Raja Grafindo).

Shihab, M. Quraish. (2020). Religious Vocabulary. (South Tangerang: Lentera Hati).

Siregar, Bismar. Interfaith Mixed Marriage How the Solution, (In Varia Judiciary Magazine; Jakarta: Number 75, December 1991.

Shihab, Umar. (2005) Contextuality of the Koran, (Cet. III; Jakarta: Penamadani).

Soekanto. Soerjano. (1986) Introduction to Legal Research (Jakarta: UI Press).

Sudarsono. (1991) National Marriage Law (Jakarta: Rineka Cipta)

Interview, Moch. Syah Ariyanto, S.H. (41 years old), Deputy Chairman of the Serui Religious Court, Monday, November 30, 2020

Interview, Sriyanto, S.H., M.H. (39 years), Serui Religious Court Judge, Friday, November 13, 2020.

Interview, Syaukani, S.Sy. (30 years old), Serui Religious Court Judge, Monday, November 16, 2020.

Interview, Moch. Syah Ariyanto, S.H. (41 years old), Deputy Chairman of the Serui Religious Court, Monday, November 30, 2020 
Interview, Sriyanto, S.H., M.H. (39 years), Serui Religious Court Judge, Friday, November 13, 2020.

Interview, Moch. Syah Ariyanto, S.H. (41 years old), Deputy Chairman of the Serui Religious Court, Monday, November 30, 2020.

Interview, Syaukani, S.Sy (30 years), Serui Religious Court Judge, Monday, November 16, 2020.Government Regulation of the Republic of Indonesia Number 45 of 1990 concerning Amendments to Government Regulation Number 10 of 1983 concerning Marriage and Divorce Permits for Civil Servants.

Interview, Nuzul Arifin Rumbouw, S.H., (25 years), Desk I (one) Officer of the Serui Religious Court, Friday, November 13, 2020. 